\title{
Correlative Light and Electron Microscopy of the Frog Adrenal Gland Cells Using Adjacent Epon-Embedded Sections
}

\author{
Yasumitsu NaKaI and Toru Iwashita
}

Received May 10, 1976

\begin{abstract}
Summary. Correlative light and electron microscopy on the same cells of the adrenal gland of the frog, Rana nigromaculata, fixed in glutaraldehyde followed by osmium tetroxide, was done using the adjacent Epon embedded sections.

Electron microscope observation revealed three different types of granule-filled secretory cells ; the noradrenaline-storing cells (NA cells) filled with intensely dense and varying shaped granules, the adrenaline-storing cells (A cells) filled with relatively less dense granules and the summer cells (STILLING, 1898) containing very large, round or polygonal granules $(0.2-1.3 \mu$ in diameter).

Light microscopically, an essential difference could be observed in the affinity to ammoniacal silver solution between NA and A cells. It was clarified that the granules of NA cells stained in black and were clearly distinguishable from the yellow- or brownstained granules in both $A$ cells and summer cells. This silver method can be applied for the light microscopic identification of the NA cells in the Epon-embedded sections. Furthermore, after immersing the thick sections in toluidine blue or methylene blue, the granules of NA cells showed much stronger affinity to both dyes than those of A cells and became dark blue and occasionally stained greenish blue in methylene blue, while the summer cells became blue and the granules of the A cells stained light blue.
\end{abstract}

Since BÄNDER (1950) first demonstrated the two different types of chromaffin cells in the mammalian adrenal glands, NA and A storing cells histochemically under the light microscope, many cytochemical studies of the adrenal chromaffin cells in various animals have been reported on both the light and the electron microscopic levels.

In the frog adrenal gland, TAKAYA (1970) demonstrated under the light microscope two distinct types of chromaffin cells by applying the argentaffin reaction and the lead hematoxylin stain to the paraffin sections, subsequent to glutaraldehyde or formalin fixation.

For the diffierentiation and the identification of the noradrenaline- and adrenalinecontaining granules on the electron microscopic level, many investigators have attempted various methods (Wood, 1963; Wood and BARnett, 1964; Coupland et al., 1964; Tramezzani et a1., 1964; Elfvin, 1965; Coupland and Hopwood, 1966). Two types of chromaffin cells have already been distinguished by using double fixation with glutaraldehyde followed by osmium tetroxide in the frog adrenal gland (BENEDECZKY, 1967). However, there has been no direct demonstration for identification of the same cells at both light and electron microscopic levels.

In the present study, silver staining and toluidine blue or methylene blue staining were respectively applied to the thick Epon-embedded sections prepared from serially adjacent sections, before and behind, the thin sections for electron microscopy, in order to distinguish and identify the two types of chromaffin cells as well as the summer cells. 


\section{Materials and Methods}

Twenty adult frogs, Rana nigromaculata, obtained in May and October, were used in this study. The frogs were sacrificed by perfusion of the fixative solution through the heart under anesthesia with MS-222 (meta aminobenzoic acid ethylester methanesulfonate, Sankyo Co., Japan). KARnovsky's glutaraldehyde-formaldehyde fixative (KARNOVSKY, 1965) or $2 \%$ glutaraldehyde solution in $0.1 \mathrm{M}$ phosphate buffer ( $\mathrm{pH} 7.4$ ) were used as the fixative solution. Immediately following perfusion the adrenal glands were resected and cut into small blocks. The blocks were then immersed in ice-cold $1 \%$ osmium tetroxide buffered with $0.1 \mathrm{M}$ phosphate for $2 \mathrm{hrs}$ and dehydrated in a graded series of ethanol and embedded in Epon 812. Thin sections for electron microscopy and thick sections ( 1 to $2 \mu$ thick) for light microscopy were alternately cut with glass knives on a Porter-Blum MT-1 microtome.

Thick sections were stained in toluidine blue or methylene blue (RICHARDSON, 1960), and the thin sections were stained for $4 \mathrm{hrs}$ at $35^{\circ} \mathrm{C}$ in ammoniacal silver solution according to the modified method of BieLschowsky (1904). The ammoniacal silver solution was prepared by the following procedure. Four drops of $40 \%$ aqueous sodium hydroxide were added to $10 \mathrm{ml}$ of $10 \%$ aqueous silver nitrate. The dark brown precipitate which appeared in the solution was dissolved by adding concentrated ammonia (28\% ammonium hydroxide) and the solution was brought to $200 \mathrm{ml}$ with distilled water.

\section{Results}

\section{Electron microscopic observations}

Two different types of chromaffin cells, summer cells (STILLING, 1898) and cortical cells were observed in the frog adrenal gland. Both types of chromaffin cells were found as clusters among summer cells and cortical cells and were spheroidal and polygonal in shape. The nuclei were eccentric. In the frog adrenal gland fixed with glutaraldehyde followed by osmium tetroxide, one type of the chromaffin-storing cells was filled with high density granules of markedly varying shape. The granules were mostly spherical in shape, but often rod and kidney-like forms were also observed. Their size ranged from 200 to $400 \mathrm{~nm}$ in diameter for the spherically shaped granules and $600 \times 200 \mathrm{~nm}$ for the rod shaped granules. In the other type of the chromaffin cells the granules were mostly round in shape with moderate or low density and they were about $300 \mathrm{~nm}$ in diameter. The former type is considered to be the NA cells and the latter, the A cells (Fig. 1, 4).

The summer cells were usually located among the groups of chromaffin cells and cortical cells. In the frog adrenal gland fixed in glutaraldehyde and osmium tetroxide the cytoplasm of the summer cells was almost completely occupied by moderately dense granules that were bounded by a limiting membrane (Fig. 1, 4). The granules were round or polygonal and were much larger than the catecholamine-containing granules of the chromaffin cells, ranging from $0.2-1.3 \mu$ in diameter. Generally, the dense substance of the granules was homogeneous and there was no clear space beneath the limiting membrane. By these characteristics of the granules, the summer cells are easily distinguishable from the chromaffin cells. 

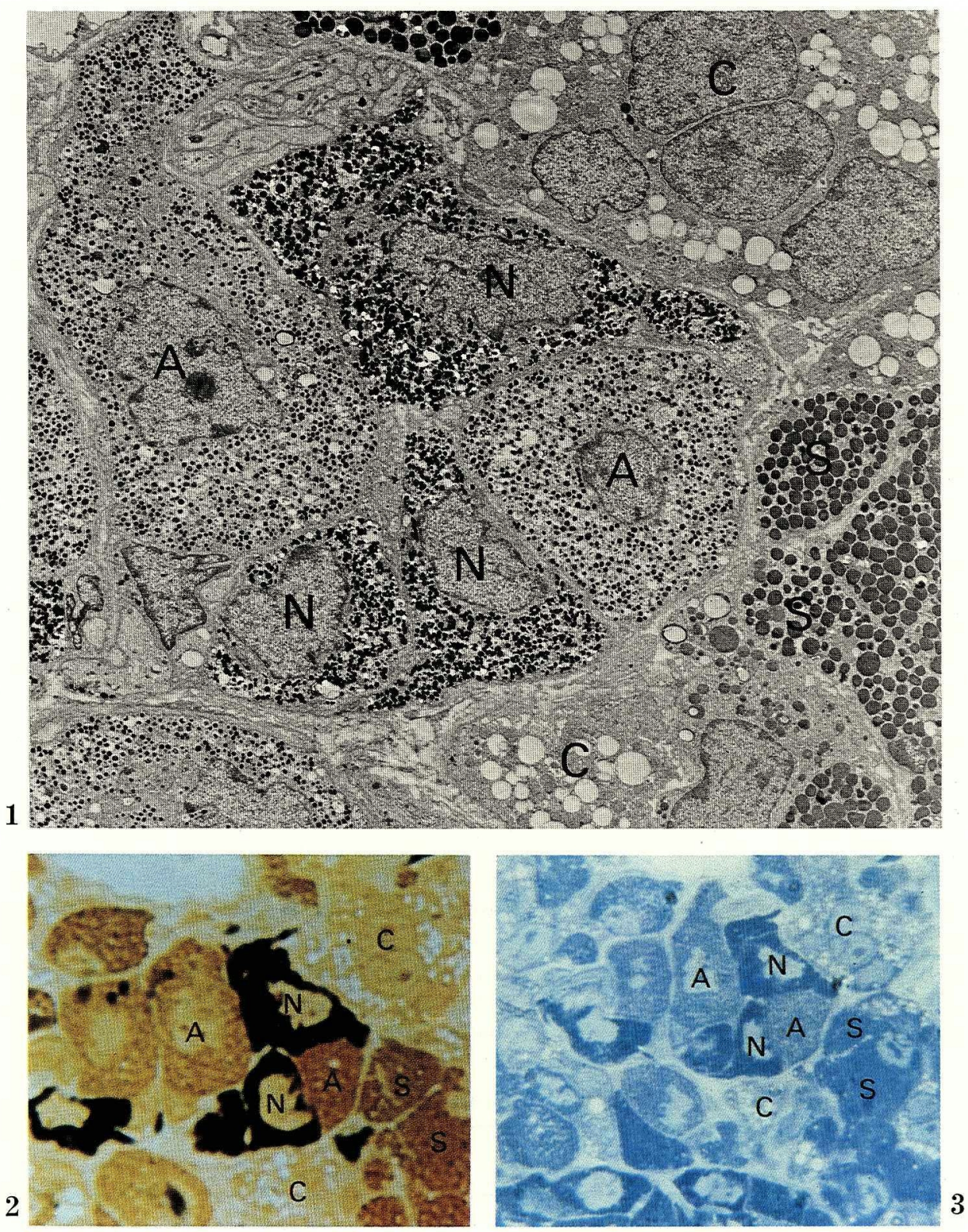

Fig. 1. Electron micrograph of the thin section adjacent to the thick sections showing the ammoniacal silver staining in Figure 2 and the toluidine blue staining in Figure 3. A A cells, $N$ NA cells, S summer cells, $C$ cortical cells. $\times 2,500$

Fig. 2. A thick section stained in ammoniacal silver solution. The NA cells $(N)$ are stained black, the A cells $(A)$ are stained light brown and the summer cells $(S)$ are also stained brown. $C$ cortical cells. $\times 900$

Fig. 3. A thick section stained with methylene blue. The NA cells $(N)$ are stained dark-blue, the summer cells $(S)$ are stained blue, and the A cells $(A)$ are stained light blue. $C$ cortical cells. 
The cortical cells were variable in shape and were scattered in small groups in the frog adrenal gland. The cytoplasm of the cortical cells was mostly occupied by a large amount of lipid droplets and numerous mitochondria presenting vesicular cristae (Fig. 1).

\section{Light microscopic observations}

\section{Ammoniacal silver staining of the thick sections}

When ammoniacal silver solution was applied to the thick sections that lay adjacent to the thin sections for electron microscopy, the cytoplasmic granules in some chromaffin cells, which proved to be NA cells in the thin section under the electron microscope (Fig. 1), stained black or dark brown (Fig. 2). On the other hand, yellow or light brown granules were observed in the cytoplasm of the chromaffin cells corresponding to the A cells, the thin section of which showed abundant round and less dense granules (Fig. 1, 2). Generally, the two types of catecholamine-storing cells were intimately in contact with each other, but distinct black granules could not be recognized in the cytoplasm of the A cells.

The granules in the cytoplasm of summer cells stained yellow or light brown and were very similar to the staining of the cytoplasmic granules of the A cells (Fig. 2). On the ammoniacal silver stained thick sections it was very difficult to differentiate the A cells and the summer cells.

The cytoplasm of the cortical cells stained light yellow and contained numerous large lucent vacuoles corresponding to lipid droplets (Fig. 2).

\section{Toluidine blue or methylene blue staining of the thick sections}

Generally, the granules in the cytoplasm of NA cells stained equally dark blue in both toluidine blue and methylene blue (Fig. 3), but at times the cytoplasm of the NA cells stained greenish blue in methylene blue (Fig. 5). The granules in the summer cells also stained purple or blue (Fig. 1,5). Compared to the NA cells, the summer cells did not show any greenish blue stain in methylene blue (Fig. 5) and appeared mostly to be lighter in color than the NA cells (Fig. 3 ), and, thus, the two cells could be distinguished without difficulty. The cytoplasm of the A cells stained light blue (Fig. 3). The staining reactions of the granules in the frog medullary cells for ammoniacal silver and methylene blue are summarized in Table 1.

Table 1. The staining affinities of the granules in the frog adrenal gland cells

\begin{tabular}{lccc}
\hline & $\begin{array}{c}\text { Noradrenaline-storing } \\
\text { cells }\end{array}$ & $\begin{array}{c}\text { Adrenaline-storing } \\
\text { cells }\end{array}$ & Summer cells \\
\hline Ammoniacal silver & black & $\begin{array}{c}\text { yellow or } \\
\text { light brown }\end{array}$ & $\begin{array}{c}\text { yellow or } \\
\text { light brown }\end{array}$ \\
\hline $\begin{array}{c}\text { Methylene blue } \\
\text { or } \\
\text { Toluidine blue }\end{array}$ & $\begin{array}{c}\text { dark blue } \\
\text { or }\end{array}$ & light blue & blue \\
\hline
\end{tabular}




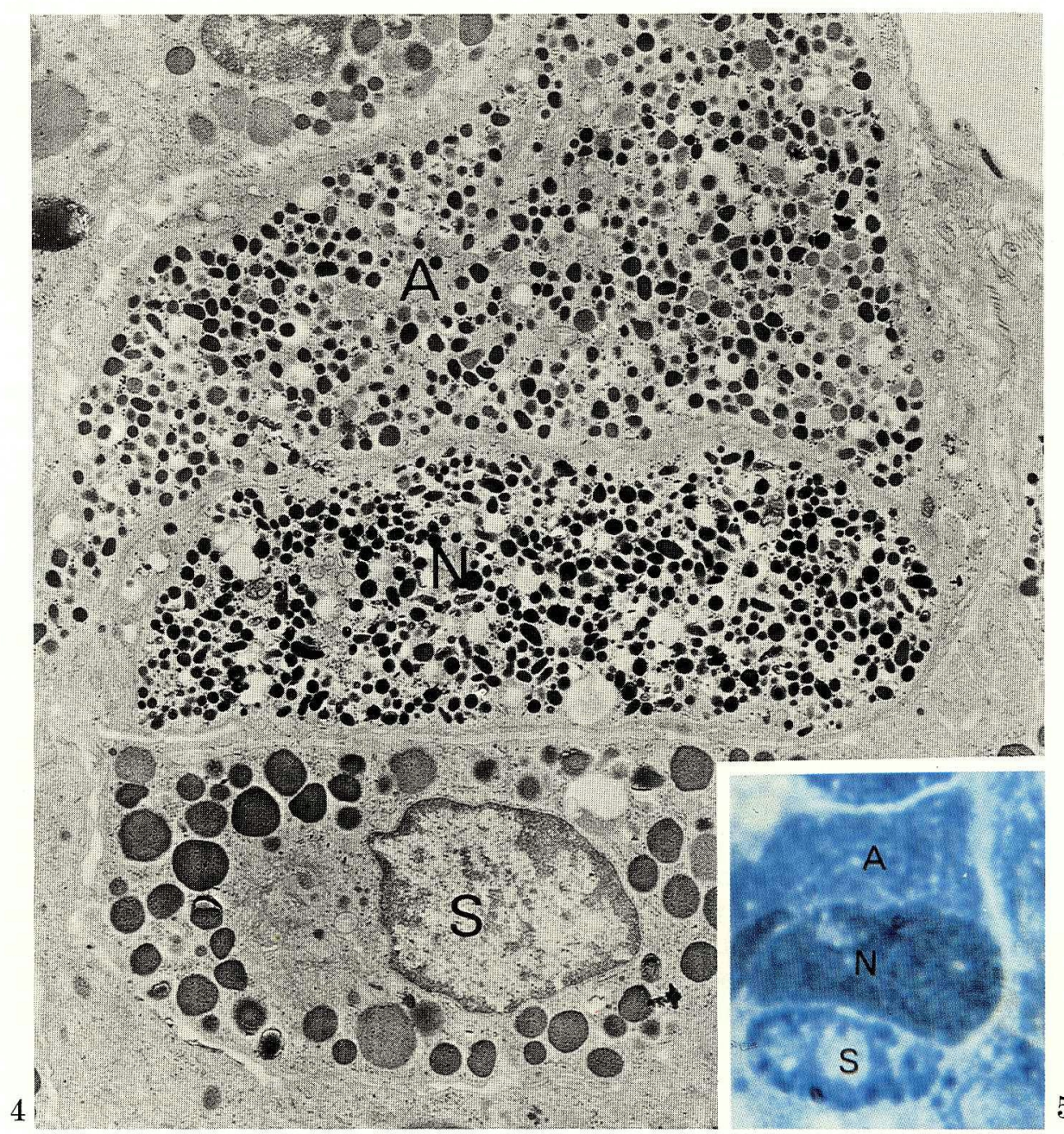

Fig. 4. Electron micrograph of the adjacent section to that showing the toluidine blue staining in Figure 5. A A cell, $N$ NA cell, $S$ summer cell. $\times 6,000$

Fig. 5. A thick section stained with methylene blue. Note the NA cell $(N)$ that is stained greenish-blue. The large blue stained granules are seen in the cy toplasm of the summer cell (S). A A cell. $\times 1,700$

\section{Discussion}

BuRgos (1959) who first observed the frog adrenal gland under the electron microscope classified three cell types: The cortical cells, the chromaffin cells — falling into only one cell type with an ability to secrete both noradrenaline and adrenaline, and the eosinophilic cells. In the frog adrenal medulla, BENEDECZKY (1967) reported that the double fixation with glutaraldehyde and osmium tetroxide revealed three kinds of medullary cells: NA cells containing high density granules with an average 
diameter of $3,250 \AA$, A cells containing varying density granules with an average diameter of $2,450 \AA$ and cells of a cortico-medullary character.

Piezzi (1967) classified two types of chromaffin cells in the toad adrenals. TAKAYA (1970) studied histochemical reactions in the frog adrenal gland under the light microscope and reported that Wood fixation (Wood, 1963) and trichrome or aniline blueeosin stain differentiated the two types of chromaffin cells, one showing brown cytoplasm and the other yellowish cytoplasm. It was also reported that the NA cells were argentaffin and the A cells were stained deep blue in lead hematoxylin after formalin or glutaraldehyde fixation. However, when fixed in Bouin, Carnoy or absolute alcohol both types of chromaffin cells were negative to the argentaffin reaction.

In order to differentiate the NA and A cells on the serial sections, thick and thin sections of Epon-embedded blocks of the adrenal gland fixed in glutaraldehyde and osmium tetroxide were alternately studied by light and electron microscopy. Applying the ammoniacal silver reaction on the thick sections, the NA cells that revealed spherical and rod-shaped high density granules on the thin section stained in black or strong dark brown, but the A cells with spherical less dense granules tinged light brown. It is supposed that this difference between NA and A cells is probably caused by much stronger chemical affinity of noradrenaline to glutaraldehyde than that of adrenaline.

In the adrenal glands of various vertebrates fixed in glutaraldehyde followed by osmium tetroxide, many authors have reported that the adrenaline-containing granules were considerably less dense than the noradrenaline-containing ones (Wood and BARnetT, 1963, 1964; Coupland et al., 1964).

TRAMEzzANi et al. (1964) reported that fine silver precipitates were observed only in the granules of the NA cells of the mammalian adrenal glands that were fixed in glutaraldehyde and treated with ammoniacal silver solution before dehydration. Both adrenaline and noradrenaline, however, were equally reduced by ammoniacal silver solution in vitro. He also postulated that the compound formed by the condensation of noradrenaline and glutaraldehyde was insoluble and the aldehyde group of the noradrenaline compound reduced the silver, while adrenaline remained soluble in glutaraldehyde. In the present study it was demonstrated in the frog adrenal gland that the granules of the NA cells in the Epon embedded section after double fixation in glutaraldehyde and osmium tetroxide were also reactive to ammoniacal silver solution.

From the radioautographic observations of the frog adrenal glands using ${ }^{3} \mathrm{H}$ noradrenaline a large number of silver grains have been recognized on the dense granules in the cytoplasm of the NA cells, but none or very few silver grains were found in the cytoplasm of the A cells which have less dense round granules (NAKAI and IwASHit A, 1973). It may be possible to consider that these labelled noradrenaline are taken up directly into the medullary cells, especially into the NA cells. As to the distinction of A cells from NA cells, it is still obscure whether the NA cells possess one type of noradrenaline-containing granules only or both types of secretory granules. Although in some cases two different types of granules co-exist in the cytoplasm of one and the same chromaffin cell, no black granules have been recognized in the cytoplasm of the A cells on the thick sections stained in ammoniacal silver solution. 
As to the light microscopic observations of the amphibian adrenal glands, Fustioni and PoRTo (1938) reported that two types of chromaffin cells, one having a strong affinity for anilline azure and azocarmine and the other having very faint affinity for both dyes, might be identified in the dichromate-fixed adrenal of the toad, Bufo arenarum. WRIGHT and Jones (1955) reported that compared to the NA cells the A cells had a higher affinity to Ehrlich's hematoxylin in the staining sections of potassium dichromate-fixed adrenal of the lizard, Lacerta viridis.

Kobayashi and Watanabe (1971) demonstrated in the freeze-dried and formaldehyde fixed adrenal medulla that the cytoplasmic granules of the A cells were selectively stained by toluidine blue and pseudoisocyanin, and suggested that the basophilic substance in the secretory granules of the A cells was the glutamate-rich soluble protein (chromogranin) and this specific protein of the A cells may possibly contain more acidic side chains than that of the NA cells. In the glutaraldehyde fixed adrenal gland of the present study the granules of the NA cells were generally much more strongly stained in toluidine blue than those of the A cells and showed occasionally greenish or yellowish blue in methylene blue. From these findings it may be considered that some substances with acidic side chains except for soluble protein (chromogranin) are much more abundantly contained in the granules of the NA cells than those of the A cells, and the granules of the NA cells containing noradrenalineglutaraldehyde compound remained insoluble during the preparation processes and probably showed metachromatic staining.

Concerning the structure and function of the summer cell of STILLING in the interrenal gland of the frog, VoLK (1972) reported that the summer cells were intimately associated with the cortical cells and contained granules which stained purple with toluidine blue and showed yellow-green fluorescence after staining with thioflavin $\mathrm{T}$. They were much larger than the granules of chromaffin cells ranging from 0.3 to $1.5 \mu$ in diameter. It was concluded that the summer cell may secrete a renin-like substance that may function in an aldosterone-stimulating renin-angiotensin system. Yoshimura and Harumiy a (1966) reported that two kinds of cortical cells, lipid and summer, were present in the frog's adrenal. The granules in the summer cells were abundant during hibernation, while during the breeding season the hypertrophied summer cells excessively increased in number and were characterized by the loss of dense granules. It was suggested that the summer cells might be derived from the lipid cells. In the present study the granules of the summer cells did not reduce the ammoniacal silver and were stained blue with methylene blue as well as with toluidine blue. From the above staining affinities and the size of the granules the summer cells were easily distinguished from the catecholamine-storing cells, though the function of the summer cell is still open to question.

\section{エポン包埋隣接切片対比によるカエル副腎細胞の光線および電子顕微鏡的研究}

$$
\text { 中井康光と岩下徹 }
$$

グルタールアルデヒドと四酸化オスミウムで二重固定したトノサマガエル (Rana nigromaculate)の副腎細胞について，エポン包埋隣接切片を用いて 同一細胞を光線および電子 


\section{顕微鏡で対比観察した.}

電顕的には，不規則形をした電子密度の高い顆粒を含むNA 細胞，電子密度の比較的低 い顆粒を含むA細胞，および球形で非常に大きい（0.2-1.3 $\mu$ 径）顆粒をもった summer 細胞の三種類の分泌顆粒含有細胞がみられた.

光顕的には，エポン包埋厚切り切片をアンモニア性銀液で染色した結果, NA 細胞の顆 粒は特異的に黑染され，A細胞および summer 細胞の両顆粒は 黄色または褐色に染色さ れ，明らかに染色性に差異がみられた. エポン包埋切片の銀染色が NA 細胞の光顕的固定 に応用できることがわかった.トルイジン青またはメチンン青による染色では NA 細胞の 顆粒は $\mathrm{A}$ 細胞の顆粒より強く染色され，濃青色を呈した。メチレン青染色で NA 細胞は 時に緑青色を呈した. 両色素に対してA 細胞の顆粒は淡青色, summer 細胞の顆粒は青色 に染色され，NA 細胞と識別できた.

\section{References}

Bänder, A.: Über zwei verschiedene chromaffine Zellen im Nebennierenmark und ihre Beziehungen zum Adrenalin- und Arterenolgehalt. Verh. Deut. Anat. Ges. 48: 172-176 (1950).

Benedeczky, I. : Electron-microscopic differentiation of cell types in the frog's adrenal medulla. Acta morphol. acad. sci. hung. 15: 271-285 (1967).

Bielschowsky, M.: Die Silberimprägnation der Neurofibrillen. J. Psychol. Neurol. 3: 169-189 (1904).

Burgos, M. H.: Histochemistry and electronmicroscopy of the three cell types in the adrenal gland of the frog. Anat. Rec. 133: 163-185 (1959).

Coupland, R. E. and D. Hopwood : The mechanism of differential staining reaction for adrenalineand noradrenaline-granules in tissues fixed in glutaraldehyde. J. Anat. (London) 100: 227-243 (1966).

Coupland, R. E., A. S. Pyer and D. Hopwood: A method for differentiating between noradrenaline- and adrenaline-storing in light and electron microscope. Nature (Lond.) 201: 1240 (1964).

Elfvin, L. G.: The fine structure of the cell surface of chromaffin cells in the rat adrenal medulla. J. Ultrastr. Res. 12: 263-286 (1965).

Fustioni, O. and J. Porto: Morphologia de las glándulas adrenales del sapo Bufo arenarum (Hensel). Rev. Soc. Argent. Biol. 14: 315-320 (1938).

Karnovsky, M. J.: A formaldehyde-glutaraldehyde fixation of high osmolality for use in electron microscopy. J. Cell Biol. 27: 137A-138A (1965).'

Kobayashi, S. and Y. Watanabe: Selective staining of A cells in the freeze-dried and formaldehyde-fixed adrenal medulla with toluidine blue and pseudoisocyanin. Arch. histol. jap. 33: 59-66 (1971).

Nakai, Y. and T. Iwashita : Electron microscopic studies on the chromaffin cells of adrenal gland of the frog, Rana nigromaculata. (Abstract). Acta anat. nippon. 48: 49 (1973).

Piezzi, R. S.: Chromaffin tissue in the adrenal gland of the toad, Bufo arenarum Hensel. Gen. comp. Endocrinol. 9: 143-153 (1967).

Richardson, K. C., L. Jarett and E. H. Finkle: Embedding in epoxy resins for ultrathin sectioning in electron microscopy. Stain Technol. 35: 313-323 (1960):

Stilling, H.: Zur Anatomie der Nebennieren. Arch. mikrosk. Anat. 52: 176-195 (1898). 
Takaya, K.: Two types of chromaffin cells in the adrenals of the bullfrog, Rana catesbeiana. A comparative study. Arch. histol. jap. 32: 69-80 (1970).

Tramezzani, J. H., S. Chiocchio and G. F. Wassermann: A technique for light and electron microscopic identification of adrenalin- and noradrenalin-storing cells. J. Histochem. Cytochem. 12: 890-899 (1964).

Volk, T. L. : Morphologic observations on the summer cell of Stilling in the interrenal gland of the American bullfrog (Rana catesbeiana). Z. Zellforsch. 130: 1-11 (1972).

Wood, J. G.: Identification of and observations on epinephrine and norepinephrine containing cells in the adrenal medulla. Amer. J. Anat. 112: 285-304 (1963).

Wood, J. G. and R. J. Barnett: Histochemical differentiation of epinephrine and norepinephrine granules in the adrenal medulla with the electron microscope. Anat. Rec. 145: 301-302 (1963). Histochem. Cytochem. 12: 197-209 (1964).

Wright, A. and I. Jones : Chromaffin tissue in the lizard adrenal gland. Nature (Lond.) 175: 1001-1002 (1955).

Yoshimura, F. and K. Harumiya : Electron microscopy of adrenal cortex cells in the hypophysectomized and ACTH administrated bullfrogs. In: Electron microscopy (6th International Congress for Electron Microscopy). Tokyo, Maruzen, 1966. (II, p. 545-546).

中井康光

干142 東京都品川区旗の台 1-5-8

昭和大学医学部

解剖学教室
Prof. Yasumitsu NAKAI

Department of Anatomy

Showa University School of Medicine

Hatanodai, Shinagawa-ku

Tokyo, 142 Japan 